\title{
Physiological effects of long-term energy-source deprivation on the survival of a marine chemolithotrophic ammonium-oxidizing bacterium
}

\author{
Brian H. Johnstone, Ronald D. Jones \\ Department of Biological Sciences and Drinking Water Research Center, Florida International University, University Park, \\ Miami, Florida 33199, USA
}

\begin{abstract}
The response of the marine chemolithotrophic ammonium-oxidizing bacterium Nitrosomonas cryotolerans was examined during energy-source deprivation. The response to starvation differed from heterotrophic bacteria in almost every aspect examined. Levels of protein, RNA and DNA remained essentially unchanged during the $10 \mathrm{wk}$ starvation period. The organism maintained an active electron transport system throughout the study. After an initial large increase, potential ammonium-oxidizing activity remained at high levels throughout starvation. The energy charge of $N$ cryotolerans was very low $(0.68)$ at the onset and decreased with starvation until 5 wk when it stabilized at 0.50 and remained constant throughout the remainder of the study. ATP remained nearly constant for $2 \mathrm{wk}$ then decreased until $4 \mathrm{wk}$ when it stabilized at $0.85 \mathrm{fmol} \mathrm{ml}{ }^{-1}$ at $10^{6} \mathrm{cells} \mathrm{ml}^{-1} \mathrm{~N}$. cryotolerans appears to be well adapted to energy-source deprivation. It is able to conserve energy by lowering its energy charge and repressing biosynthesis. It also maintained a state of readiness which allowed it to respond quickly to nutrient addition. These results indicate that this organism is well adapted to oligotrophic environments (i.e. the open ocean) where substrates are often limiting.
\end{abstract}

\section{INTRODUCTION}

In order to survive in the open ocean bacteria must adapt to the adverse conditions found there. Utilizable nutrients in the deep sea are generally present at low levels and poor in quality (Barber 1968, Menzel \& Ryther 1970, Morita 1982). Culturable bacteria are found in these environments (Morita \& Zobell 1955, Morita 1980, Torrella \& Morita 1981, Tabor et al. 1981); therefore, it can be assumed that the indigenous population of microorganisms has developed strategies to overcome nutrient deprivation.

Starvation-survival describes the physiological state of vegetative bacteria in near-zero nutrient environments (Morita 1982). The processes involved have been extensively characterized elsewhere (for reviews see Morita 1982, 1985, Dawes 1985, and Kjelleberg et al. 1987). All of the previous studies used heterotrophic bacteria.

Chemolithotrophic bacteria must also adapt to the low nutrient levels in the sea. Using immunofluores- cent direct counting techniques, Ward \& Carlucci (1985) detected a sizable population of ammoniumoxidizing bacteria in ologotrophic environments. Cell numbers of ca $10^{2} \mathrm{ml}^{-1}$ were observed. Ammonium concentrations are very low in the open ocean (generally below $500 \mathrm{n} M$ ), especially below the photic zone (Sharp 1983). This suggests that ammonium-oxidizing bacteria have developed strategies to cope with long periods of energy-source deprivation

Recently Jones \& Morita (1985b) reported on the survival of a marine ammonium-oxidizing bacterium during energy-source deprivation. This was the first starvation-survival study to use a chemolithotrophic organism. The organism, Nitrosomonas cryotolerans (Jones et al. 1988), proved to be extremely well adapted to survival during nutrient deprivation. The response of this organism to starvation differed dramatically from that of the heterotrophic bacteria previously studied (Morita 1982, 1985). For instance, unlike other bacteria, $N$. cryotolerans did not undergo fragmentation with concomitant size reduction upon starvation; 
consequently, the total number of bacteria remained the same throughout the entire study (over $6 \mathrm{mo}$ ). Furthermore, endogenous respiration reached undetectable levels by 4 wk.

In this study we have attempted to further characterize the physiological state of this bacterium under energy-source deprivation.

\section{MATERIALS AND METHODS}

Materials. All chemicals, unless otherwise stated, were obtained through Sigma Chemical Co. (St. Louis, Mo., USA).

Organism and culture. The ammonium-oxidizing bacterium used for this study was Nitrosomonas cryotolerans. The bacterium was isolated from Alaskan coastal waters and has been described in more detail by Jones \& Morita (1985b) and Jones et al. (1988). All cells used in this study were grown and maintained by continuous flow culture $\left(0.14 \mathrm{~d}^{-1}\right.$ dilution rate) in a $4 \mathrm{l}$ reaction vessel with the $\mathrm{pH}$ automatically controlled to $7.8 \pm 0.05$ by the addition of $5 \% \mathrm{~K}_{2} \mathrm{CO}_{3}$. Growth was at $5^{\circ} \mathrm{C}$ and cells were adapted to this temperature as described by Jones \& Morita (1985a) before inoculation. The medium used was as described by Jones \& Hood (1980) with the salinity adjusted to $30 \%$ using Instant Ocean Synthetic Sea Salts (IO, Aquarium Systems, Inc.). The culture was vigorously aerated with scrubbed air (i.e. all $\mathrm{CO}$ and $\mathrm{NH}_{4}{ }^{+}$were removed; Jones \& Morita 1985b) and agitated by a magnetic stirring bar.

Starvation conditions. Three liters of the culture was removed from the culture vessel; cells were then pelleted by centrifugation $\left(5080 \times g_{i} 10 \mathrm{~min} ; 5^{\circ} \mathrm{C}\right)$, washed twice with the starvation menstruum and resuspended in the starvation menstruum at a final density of ca $1.5 \times 10^{7}$ cells $\mathrm{ml}^{-1}$. The starvation menstruum consisted of $30 \%$ IO, $1 \mathrm{~g} \mathrm{l}^{-1}$ of N-2-hydroxyethylpiperazine- $\mathrm{N}^{\prime}$-2-ethanesulfonic acid (HEPES), and $1 \mathrm{ml}$ $1^{-1}$ of a $5 \% \mathrm{~K}_{2} \mathrm{CO}_{3}$ solution. The $\mathrm{pH}$ of the menstruum was adjusted to 7.8 by the addition of $1 \mathrm{~N} \mathrm{NaOH}$. The solution was filtered through a glass fiber prefilter (Gelman) to remove large particles and sterilized by autoclaving for $30 \mathrm{~min}$ at $121^{\circ} \mathrm{C}$ and $15 \mathrm{lbs} \mathrm{in}^{-2}$. The starvation flasks were capped with neoprene stoppers in order to limit ammonia contamination from the air. Ammonium was measured by the phenolhypochlorite method (Strickland \& Parsons 1972).

Viable and total direct counts. Viable counts were obtained using the Most Probable Number (MPN) method. The medium employed was essentially the same as used in the chemostat except $0.01 \%$ Phenol Red (final concentration) was added. A Petroff-Hauser counting chamber was used for total direct counts.
Ammonium oxidation. The ability of starved cells to oxidize ammonium was assayed by aseptically removing $25 \mathrm{ml}$ of the suspension in triplicate and incubating the samples in pre-chilled $\left(5^{\circ} \mathrm{C}\right) 60 \mathrm{ml}$ serum bottles with shaking at $125 \mathrm{rpm}$ in the presence of $714 \mu \mathrm{M}$ $\mathrm{NH}_{4}{ }^{+}$as $\left(\mathrm{NH}_{4}\right)_{2} \mathrm{SO}_{4}$. After 3 to $8 \mathrm{~h}$ of incubation, cells were killed with $0.5 \mathrm{ml}$ of $1 \mathrm{~N} \mathrm{HCl}$ and shaken at 150 rpm for $30 \mathrm{~min}$ at room temperature to allow the solution to warm. Nitrite production was assayed by the colorimetric method of Bendschneider \& Robinson (1952).

Respiration of starving cells. Respiration was measured indirectly by 2-(p-iodophenyl)-3-(p-nitrophenyl)5 -phenyltetrazolium chloride (INT; grade 1) reduction (Trevors et al. 1982). Triplicate samples $(25 \mathrm{ml}$ ) of starving cells were transferred to $60 \mathrm{ml}$ serum bottles. Each sample received $2.5 \mathrm{ml}$ of INT $(0.02 \%, w / v$, final concentration), and the bottles were incubated at $5^{\circ} \mathrm{C}$. After $24 \mathrm{~h}$ of shaking at $125 \mathrm{rpm}$, cells were collected on Whatman GF/F filters by vacuum filtration. Filters were placed in screw-cap test tubes and dried for $1 \mathrm{~h}$ under a stream of dry air. The INT-formazan formed was extracted for $10 \mathrm{~min}$ from the filters with $4 \mathrm{ml}$ of $100 \%$ methanol. The extract was cleared by centrifugation $\left(5080 \times g\right.$ at $5^{\circ} \mathrm{C}$ for $\left.10 \mathrm{~min}\right)$. A standard solution of INT-formazan was used to obtain the concentration of INT-formazan in the extracts. The experimental values were corrected using formalin-killed cells and $0.02 \%$ INT for the blank reaction.

Extraction and assay for adenylate energy charge $\left(E_{A}\right)$ and $A T P$. Four $m l$ of the starving suspension were collected by vacuum filtration on $0.45 \mu \mathrm{m}$ nitrocellulose filters (Gelman, GA-6). The filters were quickly placed in $20 \mathrm{ml}$ scintillation vials and boiled in $3.5 \mathrm{ml}$ of $0.02 \mathrm{M}$ Trizma-7.7 buffer for $5 \mathrm{~min}$. The extracts were stored at $-20^{\circ} \mathrm{C}$ until all of the samples had been collected. Adenylate content was measured by the luciferin-luciferase method of Karl \& HolmHansen (1978). Light emission was measured with a Biocounter M2010 photometer (RGM Industries, Inc. Titusville, Fla, USA). Light emission was integrated over a $30 \mathrm{~s}$ period. Internal standards were used to quantify the amount of recovered adenylates. Standards and blanks were treated the same as samples

Extraction and determination of RNA, DNA and protein. Triplicate $40 \mathrm{ml}$ subsamples of the culture were removed aseptically and cells were pelleted by centrifuging. The supernatant was removed by pipetting and the pelleted cells were stored at $-20^{\circ} \mathrm{C}$ until all samples were collected, at which time the cells were assayed for DNA, RNA and protein.

After resuspending in $1 \mathrm{ml}$ of filtered ice-cold distilled water, the cells were transferred to $16 \times 125 \mathrm{~mm}$ screw-cap test tubes. The tubes in which the pellets were stored were washed with an additional $1 \mathrm{ml}$ of 
Table 1. Nitrosomonas cryotolerans. Viable and direct counts during nutrient deprivation

\begin{tabular}{|ccccc|}
\hline $\begin{array}{c}\text { Time } \\
(\mathrm{wk})\end{array}$ & $\begin{array}{c}\text { Direct counts } \\
\left.\left(10^{7} \text { cells m }\right)^{-1}\right)\end{array}$ & $\begin{array}{c}\text { Confidence interval } \\
(95 \%)\end{array}$ & $\begin{array}{c}\text { Viable counts } \\
\left.\left(10^{7} \text { cells ml }\right)^{-1}\right)\end{array}$ & $\begin{array}{c}\text { Confidence interval } \\
(95 \%)\end{array}$ \\
\hline 0 & 1.2 & $0.99 \leq \overline{\mathrm{x}} \leq 1.4$ & 0.90 & $0.30 \leq \overline{\mathrm{x}} \leq 3.2$ \\
3 & 1.5 & $1.1 \leq \overline{\mathrm{x}} \leq 1.9$ & 0.63 & $0.21 \leq \overline{\mathrm{x}} \leq 1.5$ \\
10 & 1.4 & $1.2 \leq \mathrm{x} \leq 1.5$ & 0.78 & $0.25 \leq \overline{\mathrm{x}} \leq 1.9$ \\
\hline
\end{tabular}

cold distilled $\mathrm{H}_{2} \mathrm{O}$ which was also transferred to the appropriate screw-cap tubes. Final sample volume was $2 \mathrm{ml}$.

For DNA determinations, $0.1 \mathrm{ml}$ of each solution was transferred to plastic microcentrifuge tubes. The DNA assay and extraction procedures were essentially those of Labarca \& Paigen (1980) and Paul \& Meyers (1982). The cell suspension was diluted with $2 \mathrm{ml}$ of extraction buffer $\left[0.025 \mathrm{M} \mathrm{NaH}_{2} \mathrm{PO}_{4}, 0.002 \mathrm{M}\right.$ EDTA (ethylenediamine-tetraacetic acid), $0.01 \%$ Sarkosyl (International Biotechnologies, Inc.), $\mathrm{pH} 7.4$ ] and placed on ice. Cells were disrupted by sonication ( $30 \mathrm{~s}$ at $70 \mathrm{~W})$ with a Branson sonifier (model \# W220-F, Heat Systems Ultrasonics Inc., Farmingdale, NY, USA) equipped with a tapered microtip. After allowing the suspension to reach room temperature, $1 \mathrm{ml}$ of the extraction buffer without Sarkosyl, but with $3 \mu \mathrm{g} \mathrm{ml}^{-1}$ of Hoechst 33258 [bisbenzimide] was added. After $10 \mathrm{~min}$ in the dark, the mixture was assayed for DNA content with a TKO 100 minifluorometer (Hoefer Scientific Instruments, San Francisco, Calif., USA with set excitation (365 nm, 100 $\mathrm{nm}$ bandwidth) and emission (460 nm, $10 \mathrm{~nm}$ bandwidth) filters. The arbitrary units of fluorescence were compared to readings obtained using a standard DNA solution (type 1 from calf thymus, sodium salt) with both sets of readings corrected for the fluorescence of the blank (no cells). Blanks and standards were treated exactly as the samples.
The rest of the cell sample was used for RNA and protein determinations. The extraction procedure followed that of Gallant \& Suskind (1961). Perchloric acid was used for the nucleic acid extraction. RNA was assayed by the orcinol method (Mejbaum 1939). Color formation was measured by absorbance at $665 \mathrm{~nm}$ in $1 \mathrm{~cm}$ glass cuvettes. The optical density of samples was compared to a standard RNA preparation (type 3 from bakers yeast). Both samples and standards were corrected by subtracting the blank.

Protein was determined by the method of Bradford (1976) as modified by Read \& Northcote (1981). A stock dye solution $[0.25 \mathrm{~g}$ Brilliant Blue G-250, $50 \mathrm{ml} 85 \%$ (v/v) $\mathrm{H}_{2} \mathrm{PO}_{4}$ and $25 \mathrm{ml} 95 \%$ (v/v) ethanol] was diluted by adding $3 \mathrm{ml}$ to $9.4 \mathrm{ml}$ of $8.5 \% \mathrm{H}_{2} \mathrm{PO}_{4}, 4 \mathrm{ml} 95 \%$ EtOH and bringing to $100 \mathrm{ml}$ with distilled $\mathrm{H}_{2} \mathrm{O}$ for the dye-reagent. The pellet was dissolved by boiling in 1 $\mathrm{ml} N \mathrm{NaOH}$ for $10 \mathrm{~min}$. One $\mathrm{ml}$ of the dye-reagent was added to triplicate $0.1 \mathrm{ml}$ extracts. After $10 \mathrm{~min}$ color formation was measured at $595 \mathrm{~nm}$.

\section{RESULTS}

Direct counts and MPN values of the bacteria varied only slightly throughout the entire $10 \mathrm{wk}$ experimental period (Table 1). The fluctuations observed are due to statistical error or clumping of the cells.
Fig. 1. Nitrosomonas cryotolerans. Ammonium oxidation during nutrient deprivation, measured as $\mathrm{NO}_{2}$-formation. Bars represent $\mathrm{SE}$ for the mean. Points without bars indicate $\mathrm{SE}$ is less than the size of the symbol

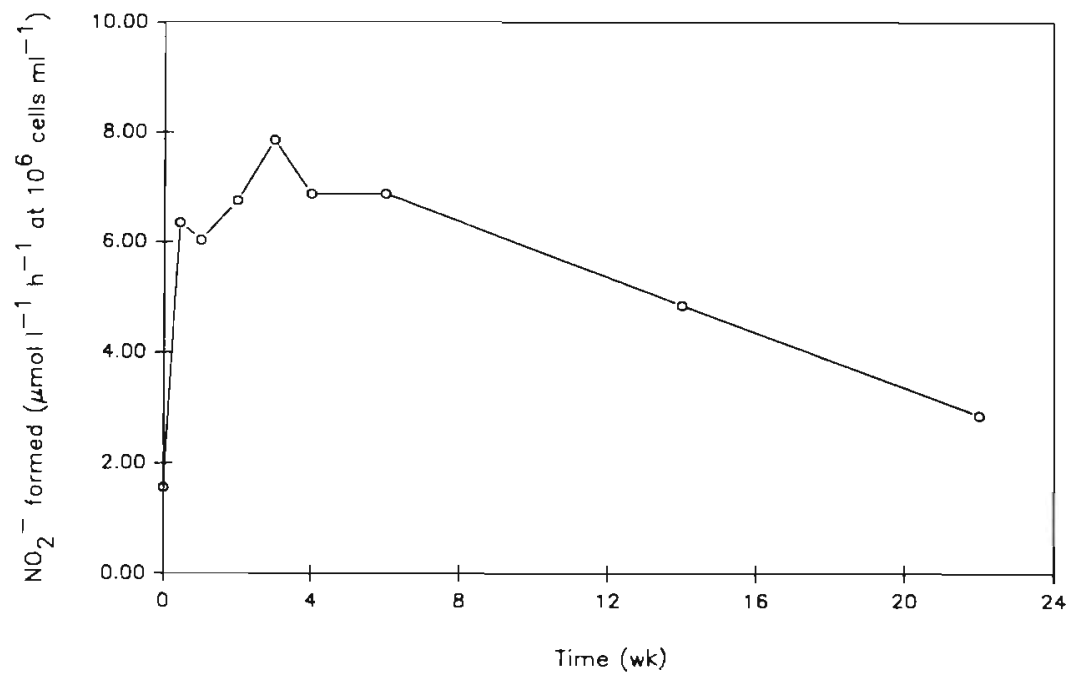




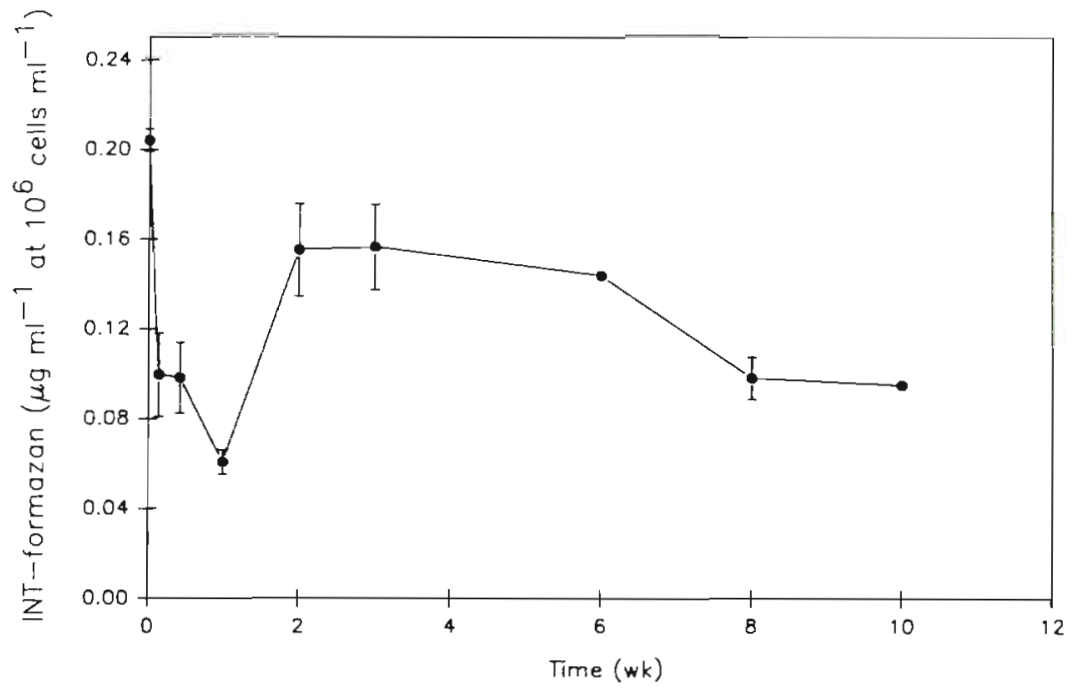

Fig. 2. Nitrosomonas cryotolerans. Electron transport system (ETS) activity during starvation, measured as INT-formazan production after $24 \mathrm{~h}$. Bars represent SE for the mean. Points without bars indicate SE is less than the size of the symbol

The rate of ammonium oxidation by the starving culture of the Nitrosomonas cryotolerans is shown in Fig. 1. Initially, the rate of oxidation increased considerably. At the onset of starvation, the rate of substrate conversion was $1.56 \mu \mathrm{mol} \mathrm{l^{-1 }} \mathrm{h}^{-1}$ but increased to
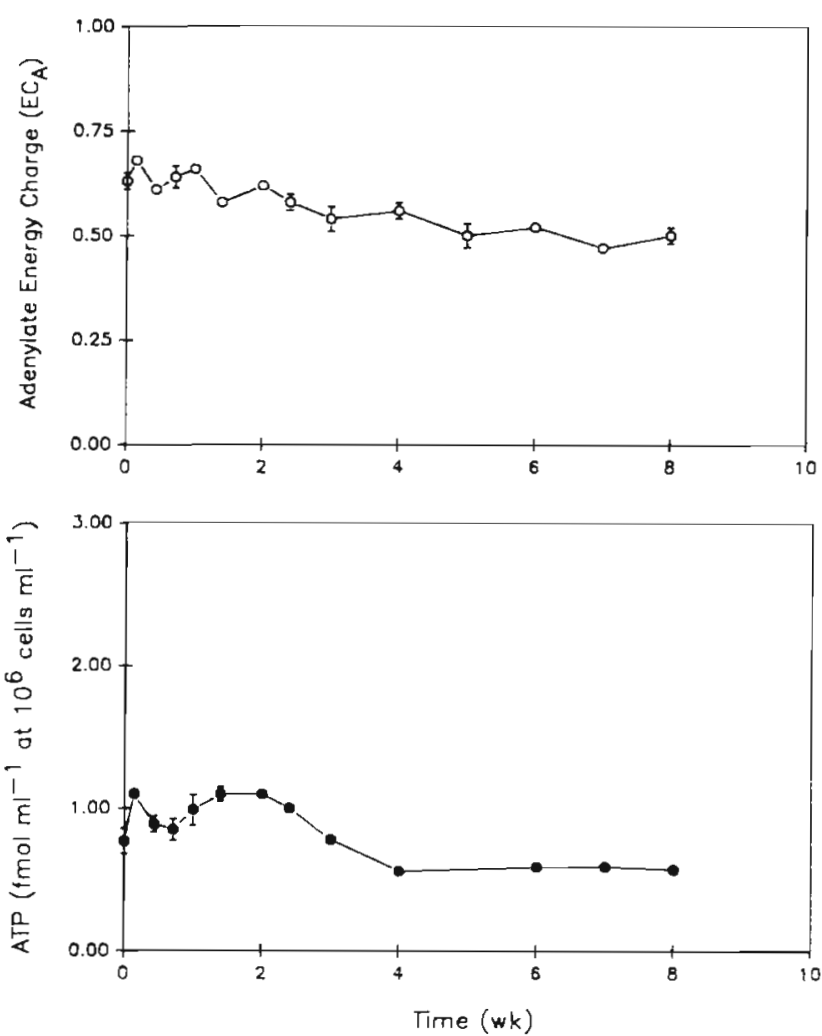

Fig. 3. Nitrosomonas cryotolerans. (a) Adenylate energy charge and (b) ATP content of starving cells. Bars represent SE for the mean. Points without bars indicate that SE is less than the size of the symbol
$7.85 \mu \mathrm{mol} \mathrm{l}^{-1} \mathrm{~h}^{-1}$ by the third week. After the peak at 3 wk, ammonium oxidation declined at a steady, gradual rate throughout the rest of the study ( $22 \mathrm{wk}$ ). At the end of the study, the rate was $36 \%$ of the peak rate. The large initial increase between the start of starvation and $3 \mathrm{~d}$ of starvation was judged to be largely artifactual, possibly resulting from the adverse effects of centrifugation. Subsequent starved cultures, centrifuged at a lesser speed and shorter time, showed a less dramatic initial increase (results not shown).

The energy state of the electron transport system. (ETS) was measured by INT-formazan production in the absence of energy-yielding substrates. Nitrosomonas cryotolerans cells maintained an active ETS during the entire starvation period (Fig. 2). ETS activity reached a minimum at $1 \mathrm{wk}$. After $1 \mathrm{wk}$ it increased to $75 \%$ of the initial value. Production of INT-formazan leveled off after 2 wk of energy source deprivation and only noticeably decreased after $6 \mathrm{wk}$ of starvation. A significant amount of ETS activity remained at the end of the study $\left(0.095 \mu \mathrm{g} \mathrm{ml}{ }^{-1}\right)$.

The adenylate energy charge $\left(\mathrm{EC}_{\mathrm{A}}\right)$ of the cells was low at the start of the study (0.68) and decreased even further as starvation progressed (Fig. 3a). The $\mathrm{EC}_{\mathrm{A}}$ decreased steadily until $5 \mathrm{wk}$ of starvation, remaining at ca 0.50 throughout the remainder of the study.

The ATP content of the cells is shown in Fig. 3b. After an initially sharp increase from 0.77 to $1.1 \mathrm{fmol} \mathrm{ml}^{-1}$ at $10^{6}$ cells $\mathrm{ml}^{-1}$ at $1 \mathrm{~d}$, the amount of ATP decreased to $0.85 \mathrm{fmol} \mathrm{ml}^{-1}$ at $10^{6}$ cells ml-1 at $5 \mathrm{~d}$. A secondary peak in ATP occurred after 2 wk of starvation. Following this peak, the concentration decreased until $4 \mathrm{wk}$ when it stabilized at ca $0.06 \mathrm{fmol} \mathrm{ml} \mathrm{m}^{-1}$ at $10^{6} \mathrm{cells} \mathrm{ml}^{-1}$, remaining at this value until the end of the experiment.

During the 10 wk period of energy deprivation the amounts of DNA, RNA, and protein remained essentially constant (Fig, 4). 
Fig. 4. Nitrosomonas cryotolerans. Amount of protein $(\Delta)$, RNA (O), and DNA $(\square)$ in cells during starvation. Bars represent SE for the mean. Data points without bars indicate that SE is less than the size of the symbol

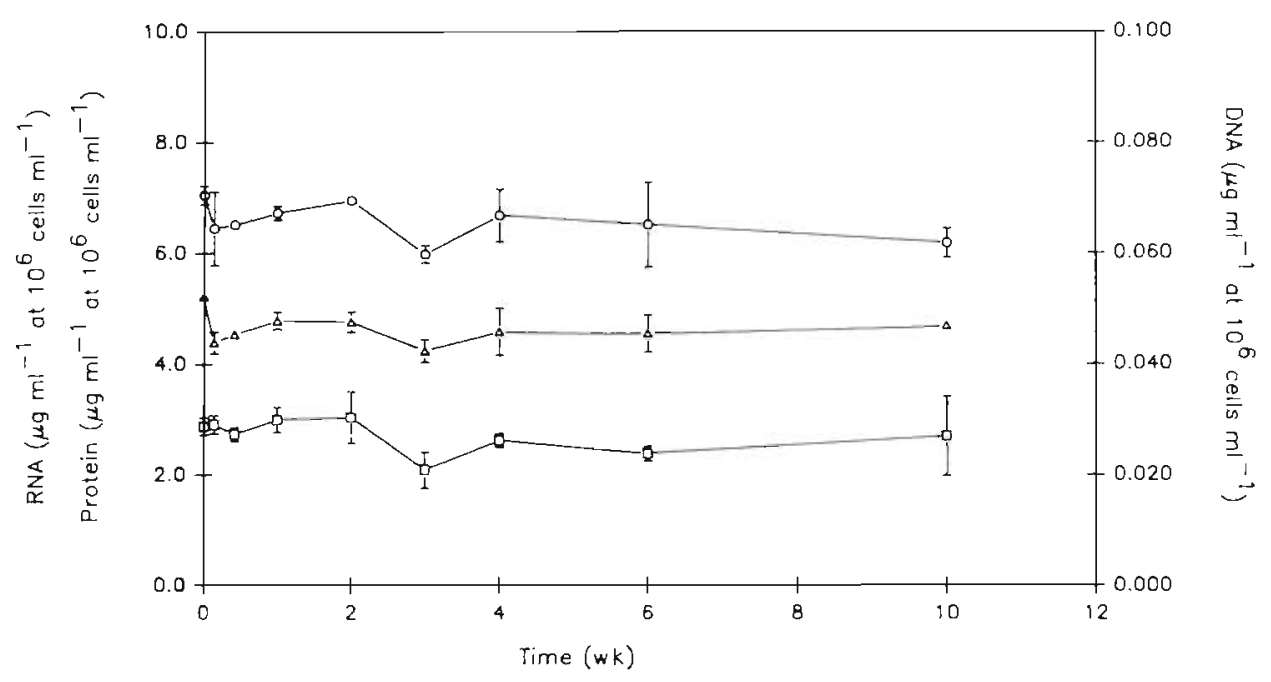

\section{DISCUSSION}

This study attempts to gain insight regarding the physiological state of a bacterium during starvation. Nitrosomonas spp. may represent a significant portion of the natural flora found in open ocean environments where the amount of fixed carbon sources for growth and energy may be extremely low (Morita 1982). Being a chemolithotroph, this organism has the advantage of using an ommipresent carbon source $\left(\mathrm{CO}_{2}\right)$ for building cellular material. Also, $N$. cryotolerans can utilize atmospheric sources of $\mathrm{NH}_{3}$ (Jones \& Morita 1985b).

Nitrosomonas cryotolerans appears to be unusual in that is does not undergo fragmentation upon starvation (Jones \& Morita 1985b) (Table 1). Furthermore, the population of viable cells does not change during longterm nutrient deprivation (Jones \& Morita 1985b) (Table 1) unlike nearly all other organisms so far studied (Morita 1982, 1985).

The ability to oxidize $\mathrm{NH}_{4}{ }^{+}$(Fig. 1) showed a different pattern than observed by Jones \& Morita (1985b): a steady decline in the oxidation rate was observed in the previous study. This probably reflects the less rigorous treatment of the starvation menstruum in this study; other than limiting air exposure and preventing $\mathrm{NH}_{4}{ }^{+}$ contamination during preparation of the menstruum, no additional steps were taken to rid the menstruum of $\mathrm{NH}_{4}{ }^{+}$. In fact a residual amount of $\mathrm{NH}_{4}{ }^{+}$(ca $5 \mu M$ ) was always present at the onset of starvation. This residual ammonium was not deamed significant, as $\mathrm{NH}_{4}{ }^{+}-\mathrm{N}$ concentrations in the starvation menstruum were undetectable after $24 \mathrm{~h}$. Additionally, cells in this study were harvested during exponential growth in a chemostat. In the previous study cells were grown in batch culture and harvested after they reached stationary phase. Growth of the cells became stationary because of the lack of available nutrients. Therefore, they were unlike cells in this study because they were nutrient-limited before starvation.

The rate of $\mathrm{NH}_{4}{ }^{+}$oxidation decreased gradually, after an initial increase during starvation (Fig. 1). As mentioned previously, the increase during the first $3 d$ may have been partially artifactual, caused by the adverse effects of centrifugation on activity. This has been seen by other researchers (Hofman \& Lees 1953, Loveless \& Painter 1968). However, it was not possible to determine whether some part of the total increase in the oxidation rate was also due to the cells response to starvation. It is possible that under energy-sufficient growth nitrifying bacteria may oxidize only a portion of the accumulated substrate. Some of the $\mathrm{NH}_{4}{ }^{+}-\mathrm{N}$ may also be allocated to protein and nucleotide base synthesis during growth. Under stress, the fraction of substrate oxidized compared to the fraction of substrate accumulated for biosynthesis would increase. This situation would be analogous to heterotrophic activity measurements with labelled organic substrates (Wright \& Hobbie 1966, Griffiths et al. 1977). In fact Kurath \& Morita (1983), using a marine Pseudomonas sp., showed that the percent respiration of L-glutamate and $\mathrm{D}$-glucose both increased initially upon starvation; subsequently declining gradually over the rest of the period. Märdén et al. (1985), monitoring oxygen uptake during starvation of a Vibrio sp., found that the percent substrate respired also increased when the cells were incubated in the presence of an unidentified nutrient source.

The decrease in the oxidation rate of $\mathrm{NH}_{4}{ }^{+}$may represent the cells need to regenerate reducing power (Jones \& Morita 1985b) which is required for the first oxidation step of $\mathrm{NH}_{4}^{+}$to $\mathrm{NH}_{2} \mathrm{OH}$ (Hooper 1969, Suzuki et al. 1976). This may cause a lag before oxidation of substrate can occur. Jones \& Morita (1985b) showed that as starvation progressed Nitrosomonas 
cryotolerans cells became increasingly less able to respond to higher concentrations of $\mathrm{NH}_{4}{ }^{*}$ The need to generate reducing power is supported by recovery experiments (Johnstone \& Jones in press) and by INT reduction data (Fig. 2). In any event, the bacterium retains a relatively high rate of substrate oxidation after almost 6 mo of starvation, suggesting that $N$. cryotolerans is well adapted to survive for long periods of time in the total absence of any energy source.

The pattern of Electron Transport System (ETS) activity (Fig. 2) closely resembles that of Ant-300, a marine psychrophilic Vibrio sp. (Amy et al. 1983a). Unlike Ant-300, the endogenous respiration of this organism reaches undetectable levels by $4 \mathrm{wk}$ of starvation (Jones \& Morita 1985b), whereas Ant-300 decreased its rate rapidly to $0.0071 \% \mathrm{~h}^{-1}$ after 1 wk of starvation, but it never reached undetectable levels during the $28 \mathrm{~d}$ experiment (Novitsky \& Morita 1977).

Dawes (1985) states that in order for vegetative bacteria to survive starvation they must maintain an energized membrane through endogenous metabolism. In this study, both dehydrogenase activity (INT reduction) and the $\mathrm{NH}_{4}{ }^{+}$oxidation rate decreased after $6 \mathrm{wk}$ of starvation. This suggests that the cells slowly become incapable of responding immediately to their energy source after the depletion of endogenous energy reserves. However, this apparently does not affect viability of this organism (Table 1).

The fact that Nitrosomonas cryotolerans reduces INT at all during long periods of starvation is surprising considering that INT-formazan granules are not detected after 4 d of starvation (Jones \& Morita 1985b). Either granule formation does not occur after this time and the reduced INT diffuses throughout the cytoplasm, or granules become too small to be visualized. The former is more plausible since the amount of INTformazan produced does not decrease by much as starvation time increases (Fig. 2) and pelleted cells still possess a red coloration after $4 \mathrm{~d}$ of starvation which is not present in nonstarved cells (unpubl. lab. obs.).

That this organism does not form INT-formazan granules yet actively respires during starvation can have a significant effect on results pertaining to the percent respiring cells of a total population in natural samples (Zimmermann et al. 1978) These authors' method relies on the direct counting of INT-formazan particles. In a population of nutrient-deprived bacteria, of which ammonium oxidizers (and other bacteria which respond similarly to starvation) are a significant portion, the number of respiring cells could be seriously underestimated.

At the beginning of starvation, the adenylate energy charge $\left(E C_{A}\right.$ ) was quite low (Fig. 3a). An EC $E_{A}$ value of 0.68 is low when compared to values for heterotrophic bacteria (Karl 1980); however, it is above the minimum
EC $C_{A}$ value of 0.50 needed for cells to remain viable (Chapman et al. 1971). Nitrosomonas cryotolerans steadily decreased its $\mathrm{EC}_{\mathrm{A}}$ to even lower levels as starvation time increased. The $\mathrm{EC}_{\mathrm{A}}$ of the cells stabilized at $5 \mathrm{wk}$ and remained 0.50 until the end of the experiment $(8 \mathrm{wk}) . \quad N$. cryotolerans apparently reduces its $E_{C_{A}}$ to the lowest level possible that will not affect viability

By maintaining a low energy charge, a nutrientstressed bacterium may conserve energy which would otherwise be required to maintain a high $\mathrm{EC}_{\mathrm{A}}$. Unless this organism has becomes dormant, maintenance process will continue to use ATP. In order to support a high $E_{A}$, a bacterium has to either produce ATP through endogenous respiration (Amy et al. 1983, Kurath \& Morita 1983) and/or extrude AMP or ADP (Chapman et al. 1971, Leps \& Ensign 1979).

During the first week, the fluctuation in ATP (Fig. 3b) shows the same pattern as that for $E_{A}$ values. In general, the same is true for the rest of the data (except at $10 \mathrm{~d}$ ); a gradual decline occurred until 4 to 5 wk when both $\mathrm{EC}_{\mathrm{A}}$ and ATP stabilized, remaining at this value for the remainder of the experiment. Injury inflicted upon the cells during preparation may be responsible for the initial low value of ATP. However, as with the ammonium oxidation rate (Fig. 1), the concentration of ATP rose soon after the initiation of starvation. The dip in ATP content (reaching a low at 5 d) followed by an increase to a secondary maxima at ca 2 wk most likely represents an adjustment by the cell to starvation. The trend in ATP content is also similar to the INT-reduction data shown in Fig. 2. This indicates that the cell attempted to adjust its adenylate content by utilizing membrane potential. Both sets of data suggest that ATP concentration and membrane potential are closely coupled in this organism.

Most published data from starving heterotrophic bacteria show a large decrease in ATP content during the early stages (Nelson \& Parkinson 1978, Amy et al. 1983, Kurath \& Morita 1983, Oliver \& Stringer 1984). Kurath \& Morita (1983) observed an initial decrease in ATP (respiring cells) ${ }^{-1}$ followed by a steady increase to levels seen at the beginning of starvation in a Pseudomonas sp.

Through the close coupling between membrane potential and ATP synthesis and through the maintenance of an active electron transport system (Fig. 2), Nitrosomonas cryotolerans is able to quickly produce more ATP in response to substrate (Johnstone \& Jones in press). Thus, ATP is supplied for active transport (Stouthamer 1973) and overcoming repressive modulation of enzymes caused by low adenylate ratios (Atkinson 1969).

Protein, RNA, and DNA concentrations in the cells changed very little or not at all during the experiment 
(Fig. 4). This differs from previous studies with heterotrophs; most have shown significant fluctuations (both positive and negative) in all 3 polymers (Novitsky \& Morita 1977, Amy et al. 1983, Hood et al. 1986). Nelson \& Parkinson (1978) found differing fluctuations in 3 soil isolates over a short-term starvation period ( $3 \mathrm{wk}$ ).

It hardly seems beneficial to degrade DNA, unless an organism has more than one copy of the genome. In this study, the DNA content was found to vary little during starvation. Other studies, in contrast, have found significant degradation of DNA (Novitzsky \& Morita 1977. Amy et al. 1983, Hood et al. 1986). Lack of degradation by Nitrosomonas cryotolerans could be a reflection of the longer generation times of chemolithotrophic organisms compared to heterotrophs (ca 60 h for N. cryotolerans; Jones \& Morita 1985a); these slow growing organisms may have fewer partial copies of chromosomal DNA.

The dip in levels of all macromolecules at $3 \mathrm{wk}$ of starvation is curious (Fig. 4) and may have simply been sampling error.

The amount of RNA per cell was relatively constant throughout the 10 wk study (Fig. 4). All previous studies have shown fluctuations in RNA during starvation. Nelson \& Parkinson (1978) found a significant decrease in the RNA content of a Pseudomonas sp. and a Bacillus sp., and a large increase in an Arthrobacter sp.; Amy et al. (1983) observed a large initial decrease with a subsequent steady increase in Ant-300; and Hood et al. (1986) found a decrease throughout the period of starvation of Vibrio cholerae.

Between the initiation of starvation and $24 \mathrm{~h}$ there was a slight decrease in protein content after which levels remained constant (Fig. 4). Nelson \& Parkinson (1978) and Amy et al. (1983) found the same with a Pseudomonas sp. and Ant-300, respectively. This drop may or may not reflect degradation of protein as an energy source; rather it may be a result of loss of proteins from cells damaged during preparation for starvation. No attempt was made to measure protein levels in the starvation menstruum or in the wash menstruum. Ant-300 appears to lose large amounts of ${ }^{35}$ S-label (protein subunits or metabolites resulting from degradation) into the medium during the initial stages of starvation (Amy et al. 1983a). Finally, Hood et al. (1986) found a relatively constant degradation of protein throughout the $30 \mathrm{~d}$ starvation period of Vibrio cholerae.

It appears that both protein synthesis (Amy \& Morita 1983, Reeve et al. 1984a, Groat et al. 1986, Jaan et al. 1986) and degradation (Amy \& Morita 1983, Reeve et al. $1984 \mathrm{~b}$ ) are normal components in the survival of heterotrophic bacteria during energy-source deprivation. Furthermore, there is temporal variability in synthesis by Escherichia coli during starvation (Groat et al. 1986). By using inhibitors of protein synthesis it was found that in E. coli the most critical products for survival were produced during the first $10 \mathrm{~h}$ of starvation (Reeve et al. 1984a). From the results obtained (Fig. 4) it does not appear that $N$. cryotolerans synthesizes any new protein during starvation. The occurrence of molecular rearrangement is still a possibility.

Though a large amount of degradation did not occur with regard to any of the macromolecules studied, other constituents of the cell may be used for energy during starvation. Previous studies have shown both decreases and increases in lipid content during starvation of marine heterotrophic bacteria (Oliver \& Stringer 1984, Guckert et al. 1986, Malmcrona-Friberg et al. 1986). The lack of degradation of DNA, RNA and protein supports the data of Jones \& Morita (1985b). In their study, they found that endogenous respiration rates quickly decrease from initially low levels to undetectable levels after 4 wk of starvation. It appears that limited reserves of energy are present in these cells which are quickly expended.

These data indicate that Nitrosomonas cryotolerans is well adapted to long-term nutrient deprivation. Degradative cellular processes are undetectable during starvation. Energy is conserved through the repression of biosynthetic pathways (Johnstone \& Jones in press) and lowering the adenylate energy charge. Despite the low metabolic activity, the cells maintained active uptake and respiratory systems. All of these traits allow for efficient competition in oligotrophic environments where brief periods of nutrient availability are dispersed between long periods of energy-source deprivation.

Acknowledgements. This research was supported by National Science Foundation grant OCE 8519210.

\section{LITERATURE CITED}

Amy, P. A., Morita, R. Y (1983). Protein patterns of growing and starved cells of a marine Vibrio sp. Appl. environ. Microbiol. 45: 1748-1752

Amy, P. S., Pauling, C., Morita, R. Y. (1983). Starvationsurvival processes of a marine vibrio. Appl. environ. Microbiol. 45: 1041-1048

Atkinson. D. E. (1969). Regulation of enzyme function. Ann. Rev. Microbiol. 23: 47-68

Barber, R. T (1968). Dissolved organic carbon from the deep waters resists microbial oxidation. Nature, Lond. 220: $274-275$

Bendschneider, K., Robinson, R. J. (1952). A new spectrophotometric method for the determination of nitrite in sea water. J. mar. Res. 11: 87-96

Bradford, M. M. (1976). A rapid and sensitive method for the quantitation of microgram quantities of protein utilizing the principle of protein-dye binding. Analyt. Biochem. 72: $248-254$ 
Chapman, A. G., Fall, L., Atkinson, D. E. (1971). Adenylate energy charge in Escherichia coli during growth and starvation. J. Bacteriol. 108: 1072-1086

Dawes, E. A. (1985). Starvation, survival and energy reserves. In: Fletcher, M., Floodgate, G. (eds.) Bacteria in their natural environments. Academic Press, New York, p. $43-79$

Gallant, J., Suskind, S. R. (1961). Relationship between thymineless death and ultraviolet inactivation in Escherichia coli. J. Bacteriol. 82: 187-194

Griffiths, R. P., Hayasaka, S. S., McNamara, T M., Morita, R. Y (1977). Comparison between two methods of assaying relative microbial activity in marine environments. Appl. environ. Microbiol. 34: 801-805

Groat, R. G., Schultz, J. E., Zychlinsky, E., Bockman, A., Matin, A. (1986). Starvation proteins in Escherichia coli. Kinetics of synthesis and role in starvation survival. J. Bacteriol. 168: 486-493

Guckert, J. B., Hood, M. A., White, D. C. (1986). Phospholipid ester-linked tatty acid profile changes during nutrient deprivation of Vibrio cholerae: increases in the trans/cis ratio and proportions of cyclopropyl fatty acids. Appl. environ. Microbiol. 52: 794-801

Hofman, T., Lees, H. (1953). The biochemistry of the nitrifying organisms. 4. The respiration and intermediate metabolism of Nitrosomonas. Biochem. J. 54: 579-583

Hood, M. A., Guckert, J. B., White, D. C., Deck, F. (1986). Effects of nutrient deprivation on lipid, carbohydrate, DNA, RNA, and protein levels in Vibrio cholerae. Appl. environ. Microbiol. 51. 788-793

Hooper, A. B. (1969). Lag phase of ammonia oxidation by Nitrosomonas europaea. J. Bacteriol. 97: 968-969

Hooper, A. B, Terry, K. R. (1974). Photoinactivation of ammonia oxidation in Nitrosomonas. J. Bacteriol. 119: 899-906

Jaan, A. J., Dahllof, B., Kjelleberg, S. (1986). Changes in protein composition of three bacterial isolates from marine waters during short periods of energy and nutrient deprivation. Appl, environ. Microbiol. 52: 1419-1421

Johnston, B. H., Jones, R. D. (in press). Recovery of a marine chemolithotrophic ammonium oxidizing bacterium from long-term energy-source deprivation. Can. J. Microbiol.

Jones, R. D., Hood, M. A. (1980). Effects of temperature, $\mathrm{pH}$, salinity, and inorganic nitrogen on the rate of ammonium oxidation by nitrifiers isolated from wetland environments. Microb. Ecol. 6: 339-347

Jones, R. D., Morita, R. Y (1985a). Low-temperature growth and whole-cell kinetics of a marine ammonium oxidizer. M.ar Ecol. Prog. Ser. 21 239-243

Jones, R. D., Morita, R. Y (1985b). Survival of a marine ammonium oxidizer under energy-source deprivation. Mar. Ecol. Prog. Ser 26: 175-179

Jones, R. D., Morita, R. Y., Koops, H.-P., Watson, S. W (1988). A new marine ammonium-oxidizing bacterium, $\mathrm{Ni}$ trosomonas cryotolerans sp. nov. Can. J. Microbiol. (in press)

Karl, D. M. (1980). Cellular nucleotide measurements and application in microbial ecology. Microbiol. Rev. 44 : $739-796$

Karl, D. M., Holm-Hansen, O. (1978). Methodology and measurement of adenylate energy charge ratios in environmental samples. Mar. Biol 48: 185-197

Kjelleberg, S., Hermannsson, M., Mardén, P., Jones, G. W (1987). The transient phase between growth and nongrowth of heterotrophic bacteria, with emphasis on the marine environment. Ann. Rev. Microbiol. 41: 25-49

Kurath, G., Morita, R. Y. (1983). Starvation-survival physiolo- gical studies of a marine Pseudomonas sp. Appl. environ. Microbiol. 45: 1206-1211

Labarca, C., Paigen, K. (1980). A simple, rapid, and sensitive DNA assay procedure. Analyt Biochem. 102: 344-352

Leps, W. T., Ensign, J. C. (1979). Adenylate nucleotide levels and energy charge in Arthrobacter crystallopoietes during growth and starvation. Arch. Microbiol. 122: 69-76

Loveless, J. E., Painter, H. A. (1968). The influence of metal ion concentration and $\mathrm{pH}$ value on the growth of a Nitrosomonas strain isolated from activated sludge. J. gen. Microbiol. 52: 1-14

Malmcrona-Friberg, K., Tunlid, A., Mårdén, P., Kjelleberg, S., Odham, G. (1986). Chemical changes in cell envelope and poly- $\beta$-hydroxybutyrate during short term starvation of marine bacterial isolates. Arch. Microbiol. 144: 340-345

Mårdén, P., Tunlid, A., Malmcrona-Friberg, K., Odham, G., Kjelleberg, S. (1985). Physiological and morphological changes during short term starvation of marine bacterial isolates. Arch. Microbiol. 142: 326-332

Mejbaum, W. Z. (1939). Uber die Bestimmung kleiner Pentosemengen, insbesondere in Derivaten der Adenylsäure. Hoppe-Seyler's Z. Physiol. Chem. 258: 117-120

Menzel, D. W., Ryther, J. H. (1970). Distribution and cycling of organic matter in the oceans. In: Organic matter in natural waters. Hood, D. W (ed.) Institute of Marine Science Occasional Publication No. 1. University of Alaska, College, p. 31-54

Morita, R. Y (1980). Microbial life in the deep sea. Can. J. Microbiol. 26: 1375-1385

Morita, R. Y. (1982). Starvation-survival of heterotrophs in the marine environment. In: Advances in microbial ecology, Vol. 6. Marshal, K. C. (ed.) Plenum Publ. Corp., New York, p. $171-198$

Morita, R. Y. (1985). Starvation and miniaturization of heterotrophs, with special emphasis on maintenance of the starved viable state. In: Bacteria in their natural environments: the effect of nutrient conditions. Fletcher, M., Floodgate, G. (eds.) Academic Press, New York, p. $111-130$

Morita, R. Y., Zobell, C. E. (1955). Occurrence of bacteria in pelagic sediments collected during the Mid-Pacific Expedition. Deep Sea Res. 3: 66-73

Nelson, L. M., Parkinson, D. (1978). Effect of starvation on survival of three bacterial isolates from an arctic soil. Can. J. Microbiol. 24: 1460-1467

Novitsky, J. A., Morita, R. Y (1977). Survival of a psychrophilic marine vibrio under long-term nutrient starvation. Appl. environ. Microbiol. 33: 635-641

Oliver, J. D. Stringer, W F., (1984). Lipid composition of a psychrophilic marine Vibrio sp. during starvation induced morphogenesis. Appl environ. Microbiol. 47: 461-466

Paul, J. P., Meyers, B. (1982). Fluorometric determination of DNA in aquatic microorganisms by use of Hoechst 33258 . Appl. environ. Microbiol. 43: 1393-1399

Read, S. M., Northcote, D. H. (1981). Minimization of variation in the response to different proteins of the Coomassie Blue $G$ dye-binding assay for protein. Analyt. Biochem 116: $53-64$

Reeve, C. A., Amy, P. S., Matin, A. (1.984a). Role of protein synthesis in the survival of carbon-starved Escherichia coli K-12. J. Bacteriol. 160: 1041-1046

Reeve, C. A. Bockman, A. T., Matin, A. (1984b). Role of protein degradation in the survival of carbon-starved Escherichia coli and Salmonella typhimurium. J. Bacteriol. 157: $758-763$

Sharp, J. H. (1983). The distribution of inorganic nitrogen and dissolved and particulate organic nitrogen in the sea. In: 
Carpenter, E. J., Capone, D. G. (eds.) Nitrogen in the marine environment. Academic Press, New York, p. 1-35

Stouthamer, H. A. (1973). A theoretical study of the amount of ATP required for synthesis of microbial cell material. Antonie van Leeuwenhoek J. Microbiol. Serol. 39: 545-565

Strickland, J. D. H., Parsons, T R. (1972). A practical handbook of seawater analysis. Bull. Fish. Res. Bd Can. 167

Suzuki, I., Kwok, S.-C., Dular, U. (1976). Competitive inhibition of ammonia oxidation in Nitrosomonas europaea by methane, carbon monoxide or methanol. FEBS Lett. 72 : $117-120$

Tabor, P. S., Ohwada, K, Colwell, R. R. (1981). Filterable marine bacteria found in the deep sea: distribution, taxonomy and response to starvation. Microbiol. Ecol. 7: 67-83

Torrella, F., Morita, R. Y (1981). Microcultural study of bacterial size changes and microcolony and ultramicrocolony formation by heterotrophic bacteria in seawater. Appl. environ. Microbiol. 41. 518-527

Trevars, J. T., Mayfield, C. I., Inniss, W. E. (1982). Measurements of electron transport system (ETS) activity in soil. Microbiol. Ecol. 8: 163-168

Ward, B. B., Carlucci, A. F. (1985). Marine ammonia- and nitrite-oxidizing bacteria: serological diversity determined by immunofluorescence in culture and in the environment. Appl. environ. Microbiol. 50: 194-201

Wright, R. T., Hobbie, J. E. (1966). Use of glucose and acetate by bacteria and algae in aquatic ecosystems. Ecology 47 : $457-464$

Zimmermann, R., Iturriaga, R., Becker-Brick, L. (1978). Simultaneous determination of the total number of bacteria and the number thereof involved in respiration. Appl. environ. Microbiol. 36: 926-935

This article was presented by Professor R. Y. Morita; it was accepted for printing on August 31, 1988 